RESTRICTED

E/CEPAL/R. 219

March, 1980

CEPAL

ORIGINAL: ENGLISH

COMISION ECONOMICA PARA AMERICA LATINA

Meeting of Experts on the Caribbean in the Eighties

Barbados, 19-21 May, 1980

\title{
THE CARIBBEAN AND THE NEW INTERNATIONAL ECONOMIC ORDER*
}

William G. Demas

Caribbean Development Bank

*This article appeared in the August 1978 issue of the Journal of Interamerican Studies and is reproduced here for the use of the participants in the Meeting of Experts on the Caribbean in the Eighties by kind permission of the above journal. 
WILLIAM G. DEMAS

Carihtrean Devekpment Bank

Si. Mirhat. Barhade.s. W. I.

THE CARIBBEAN AND THE NEW INTERNATIONAL ECONOMIC ORDER

\section{Caribhean Political Economy}

WHAT IS THE CARIBBEAN:

Definition of categories is an age-old scholastic and often sterile pastime. But in discussing the Caribbean, definitions are essential, particularly in these days when there is growing fuzziness as to what constitutes the Caribbean.

The fact is that there are three separate but overlapping definitions of the Caribbean in widespread use today.

First, there is the English-speaking Caribbean or the Commonwealth Caribbean or West Indies. Nearly all of these countries and territories are member states of the Caribbean community which comprises the four relatively "more developed countries" of Barbados. Guyana, Jamaica, and Trinidad and Tobago, and the generally smaller eight relatively "less

AUTHOR'S NOTE: Acknowledgments are due to (wo of my colleagues at (DH: Rupert Mullings, for making useful comments on the first draft of the paper, and Herman Girant. for preparing the statistical appendix. 
developed" countries of Antigua, Belize, Dominica, Grenada, Montserrat, St. Kitts-Nevis-Anguilla, St. Lucia, and St. Vincent. Outside the community are the Bahamas (which nevertheless have informal inks with the community) and the tiny British colonies of the British Virgin Islands, Cayman Islands, and Turks and Caicos lslands. These are all islands, with the exception of the mainland terzitories of Relize (in Central America) and Guyara (in South America).

Alt the member states of the Caribbean community, with the exception of the mainland countries of Belize and Guyana, were united in the West Indies Federation for a shor period from 1958 to 1962 . The Federation was the first West Indianwide attempt at political and economic integration but it failed for a variety of reasons, including growing island nationalism and the fear that, in the absence of large amounts of British financial aid, tae bigger and slightly less poor islands would have to carry the smaller and poorer islands.

More recently an attempt has been made to achieve economic integration among the English-speaking Caribbean countries through the formation in 1968 of the Caribbean Free Trade Association (CARIFTA), which developed in 1973-1974 into the Caribbean community. The community pursues purely economic integration among its member states through the Caribbean common market. Et also pursues so-called "functional cooperation" in many areas, particularly sea and air transport, university and general education, and health. In some cases such cooperation includes common services, as in university education and shipping. Finally, the community seeks to achieve coordination of the foreign policies of its independent member states.

Second, there is the area comprising the first group of countries plus Cuba, Dominican Republic, Haiti, Puerto Rico, the U.S. Virgin Islands, Suriname, the Netherlands Antilles, and the three French departments of Martinique, Guadeloupe, and Cayenne. This area is often referred to as the Caribbean Archipelago. It consists of all the islands in the Caribbean 
sea together with the mainiand countries of Belize, Guyana, Cayenne, and Suriname.

Mcre recently a broader concept of the Caribbean has been advanced in some quarters. This is the sc-called Caribbean basin comprising the Archipelago countries as well as those mainland cowntries whose shores are washed by the Caribbean sea-that is, Mexico, the five Cerital American Republics, Panama, Colombia, and Venezueia.

In fact, one can depict these three concepts of the Caribbean in terms of three concentric circles. Using mathematical notation, $\mathbb{C}_{1}$ would be the English-speaking Caribbean, $\mathbb{C}_{2}$ the $C_{2}$ ribbean Archipelago, and $C_{3}$ the Caribbean basin, and we would have $C_{3}>C_{2}>C_{1}$.

\section{THE CARIBDEAN ARCHIPELAGO}

Anyone with even a superficial knowledge of the history of Latin America generally and the area in particular knows that the historically and culturally valid definition of the Caribbean is that of the Caribbean Archipelago, or $C_{2}$. This essay focuses, therefore, on the Archipelago-although the Englishspeaking Caribbean, $C_{1}$, will be dealt with extensively.

The countries and territories of the Caribbean area as here defined have a combined land area of 281,421 square miles and a total population of 28 million, making the area a potentially economically viable one--if the several formidable barriers in the way of integration could ever possibly be overcome.

When we look closely at the countries and territories of the Caribbean Archipelago, we find a variety of levels of constitutional development, types of political systems, economic ideologies, and development strategies, as well as considerable variation in size, population, and endowment of natural resources and linguistic and cultural patterns. 
The independent countries of the area are (in order of year of achievement of independence) Haiti, Dominican Republic, Cuba in the nineteenth century, and, beginning in 1962, Jamaica, Trinidad and Tobago, Guyana, Barbados, Bahamas, Grenada, and Suriname. (It should be noted that the English-speaking countries and Suriname achieved their independence in the 1960s and 1970s.)

All the other countries of the Caribbean area ate politically dependent territories. Puerto Rico has a unique status of Free Associated State with the United States involving a very close political relationship with the United States of whose customs and currency areas it forms part. The same applies to the U.S. Virgin Islands, except that the extent of internal autonomy is less than in Puerto $\mathbb{R}$ ico.

The English-speaking politically dependent territories include the British associated states, which have full internal self-government, but with Britain still being responsible for defense and external affairs. There are five colonies-.-internally self-governing Belize on the Central American mainland and the four very small individual islands or groups of islands of British Virgin Islands, Cayman Islands, Montserrat, and Turks and Caicos Islands.

The Netherlands Antilles consist of a federation of six selfgoverning islands, with the Kingdom of the Netherlands being responsible for defense and external affairs. The Netherlands Antilles, like the Associated States of Britain, are more fully internally self-governing than Puerto Rico and the U.S. Virgin Islands.

The English- and Dutch-speaking territories were, until recently, involved in reciprocal preferential trade agreements with their respective metropolitan countries, but these preferential agreements have now been replaced by the Lomé Convention on trade and aid between the EEC and the independent countries, and between the EEC and the dependent territories under Part IV of the Treaty of Rome. These new arrangements 
have abolished the "reverse" preferences which the associated countries and territories formerly granted to the metropolitan countries.

Finally, we should mention the French Overseas departments of Martinique, Guadeloupe, and Cayenne which are juridically parts of metropolitan France and which participate directly in French elections.

There is considerable variety in political systems and economic ideologies. Cuba has a centrally planned socialist economy and close economic ties with the Soviet Union and recently became a full member of COMECON. Guyana and Jamaica are moving toward Third World socialism and democratic socialism, respectively. Dominican Republic and Haiti tend to be rather conservative in their economic ideologies. The other independent countries of the area-Bahamas, Barbados, Grenada, Suriname, and Trinidad and Tobago-have more or less "centrist" ideologies, Barbados having a fairly well-deveioped "Welfare State" and Trinidad and Tobago being somewhat more "left" (in the sense of a larger state-owned sector and conscious policies of income redistribution) than the others.

The politically dependent territories obviously have less freedom of choice in such matters. Puerto Rico and the U.S. Virgin Islands are highly integrated in a very dependent manner into the U.S. economy, with free emigration opportunities to the metropolis, and also receive a high level of welfare-oriented transfer payments from the Mainland. Puerto Rico's development strategy has over the last three decades resulted in a large increase in per capita income and exports of manufac. tured goods which now exceed the traditional exports of sugar, tobacco, and the needlework industries. But unemployment remains high, the food-producing sector is depressed, and the problem of a more equitable distribution of income remains.

Economic and financial integration between France and her three Caribbean overseas departments goes so far as to 
make it impossible to talk of the "national economy" of any of the three departments. Their economies are the most highly artificial in an area in which there is considerabie artificiality of national economies. There exists nothing even remotely approaching the levels of production in agricudture, industry, and tourism achieved in highly dependent Puerto $\mathfrak{R}$ ico. The economies produce virtually nothing and rest to an alarming extent on the basis of massive transfer payments from France.

In the remaining British Associated States, colonies, and the Netherlands Antilles there is a smaller degree of dependent integration into the metropolitan economies than in the U.S. territories and the French departments.

\section{Size, Population, and Natural Resources}

Marked differences in geographical size, population, and natural resource endowment also exist.

The northwest islands of the Greater Antilles are much larger than those of the Lesser Antilles in the east. Cuba, the largest Caribbean island, has a population of over 9 million and a land area of 44,000 square miles. It is not densely populated and is fairly well endowed with large areas of land suitable for agriculture and livestock and with mineral deposits of nickel and copper. Dominican Republic and Haiti have populations of roughly $4 \frac{1}{2}$ million each and areas of 19,000 and 11,000 square miles respectively; but Haiti has a much denser population ( 428 as against 251 persons per square mile) on the smaller and more mountainous and infertile part of the island of Hispaniola, which it shares with the Dominican Republic. Haiti has relatively small deposits of bauxite and copper and some hydroelectric potential, while the Dominican Republic has deposits of bauxite, copper, and nickel. Puerto Rico has no significant mineral deposits (except copper) and a high population density of 900 persons per square mile. Jamaica, the other country forming part of the Greater Antilles, has like Haiti, large areas of mountainous terrain, but is somewhat better endowed for agricultural and livestock production than Haiti. It has a 
population density of 463 persons per square mile. On the other hand, it is very richly endowed with bauxite, in the production of which it is, after Australia, the world's largest supplier. All the islands of the Greater Artilles have very good tourism potential.

Generally speaking, the islands of the Lesser Antilles are geographically smaller in size, have small and very dense populations and little, if any, by way of mineral resources. Trinidad and Tobago, the largest of the Lesser Antilles, has a population of 1 million; Barbados 250,000; and the seven English-speaking Leeward and Windward Islands have very small populations with the largest, Grenada and St. Lucia, having approximately 110,000 inhabitants. Like those in the Greater Antilles, nearly all the islands of the Lesser Antilles have sun, sea, and beaches which constitute tourist attractions. The only significant producer of minerals in this group is Trinidad and Tobago, which, however, is a minor producer of oil by world standards.

The mainland countries of Belize, Guyana, Suriname, and Cayenne have much bigger land areas, but very low population densities. They all have considerable by no means yet fully exploited agricultural, livestock, and forestry potential and, in the case of Guyana and Suriname, considerable deposits of bauxite and other minerals such as gold. In addition, there are rich fishing and shrimp banks off the three Guianas.

\section{Differences in Language and Cullure}

Apart from these constitutional, political, economic, and geographical differences between the countries and territories of the Caribbean area, there are certain linguistic and cultural differences-French influence in Haiti; Spanish in Cuba, Dominican Republic, and Puerto Rico; English in the Commonwealth Caribbean; Dutch in Suriname and the Netherlands Antilles; French in the three overseas departments of France. 
In the face of such bewildering variety, is there any meaning as to whether the countries of the Caribbean Archipelago in any way have much in common with each other? It is possible to highlight many common features of these countries. These common features spring from history and geography.

To students of Caribbean history it is obvious that the Caribbean Archipelago countries have a common historical legacy: the sugar plantation, slavery, indentured labor, monocultural economies producing what they did not consume and consuming what they did not produce, a heavy African input into their populations and many common cultural features associated with this in spite of linguistic differences, and (with the exception of Haiti) perhaps the longest period of external political dependence of any part of the Third World. Finally, there is the fact that, in spite of the sea which separates them, they all belong to a geographically distinct part of the world. (It is this disinciness, this Caribbean identity, which makes for the inclusion of the Mainland countries of Belize, Guyana, Suriname, and Cayenne side by side with the Archipelago islands in the Caribbean area.)

At the same time, historically the economies have been highly dependent on the various metropolitan countries in terms of rrade, transport, and communications, technology, direct foreign investment, and, more recently, economic aid as well as outlets for emigration (including the brain drain). In one word, the historical legacy of these countries can be said to be one of extreme external economic dependence and lack of "linkages" between the various sectors of the national economies of each country and between the sectors of the various countries. Intra-area trade and other economic transactions were unable to develop to any significant extent, the individual countries being tied "vertically" to their particular metropolitan country rather than "horizontally" with each other.

Even today the Caribbean remains one of the most highly economically fragmented, dependent, and "balkanized" areas 
of the Third World, both politically and economically. Very obviously, they are separated by the sea. The islands and the mainland countries of Belize in Central America and Guyana, Suriname, and Cayenne on the South American mainland are geographically separated by the sea-a very effective barrier in the absence of an excellent system of sea and air transportation and of telecommunications, which does not yet exist.

Nevertheless, whatever may ice the shortcomings of most of the individual Caribbean countries and territories from the point of view of resources, population size, and markets, it is clear that the Caribbean area, regarded as a group, has a reasonably large population of just under 30 million and a fairly good and diversified natural resource base-agricultural land, livestock potential, forestry resources, fisheries, bauxite, nickel, copper, oil, natural gas, hydroelectric power, and the sun, sea, and sand required for a certain sype of tourism. (The full mineral potential of the three Guianas is also yet unknown.)

What is true of the 30 -million Caribbean area is also true of the 5-million Caribbean community. Regarded as a group, they have, in relation to their total population, almost as wide a range of natural resources as the wider Caribbean Archipelago, whatever may be their natural resource and demographic limitations at the individual country level.

Nervertheless, one must realistically admit that the individual countries and territories of both the Caribbean community and the wider Caribbean Archipelago countries suffer from certain disadvantages in terms of their autonomous economic development. These disadvantages are the legacy of external dependence combined with small size of population and a narrow range of natural resources at the individual country level.

The historical legacy of dependence is not in dispute. There is, however, a more lively debate concerning the effects of small size on the capacity for autonomous economic devel- 
opments; questions are even often raised as to whether small island populations of less than 100,000 can with any meaning maintain the substance of their political independence, once they achieve it.

In discussing the legacy and the present reality of external economic dependence, we have to draw immediate attention to an economic fact that is of the highest importance for an uncierstanding of the Caribbean economy today-the existence of per capita incomes in both the politically dependent and independent couniries of the area (except for $\mathrm{H}^{\mathrm{T}} \mathrm{a} i \mathrm{i}$ ) that are relatively high by Third World standards. But, paradoxically enough, the extremely long history of Caribbean external economic dependence and close association with the metropolitan countries has resulted in glacially slow and gradual "trickle-down" effects. Nevertheless, the relatively high levels of per capita income are a highly misleading and inappropriate index $o_{s}^{s}$ the present level of economic development of the countries and territories of the area. They have to be qualified to take account of the very high levels of unemployment and underemployment, of an often high degree of inequality of income distribution, of lagging and backward food-producing sectors, and of an undiversified structure of production and exports. Even more fundamentally, the per capita income figure conceals the true nature of economic underdevelopment, which is a distorted and highly unbalanced economic structure incapable of meeting the basic needs of the rural and urban masses and lacking in internal economic resilience in the face of adverse economic impacts of external origin. Thus, the Caribbean economies, in spite of the relatively high levels of per capita income, are riddled with all the features of "dependent underdevelopment."

In discussing the issue of size, I cannot go into all the ramifications of this debate except to stress that those who do not see any inherent disadvantages in small size stress the pólitical and cultural will of the people of a very small country to survive and the need for indigenous technological innovation in such countries. They sometimes even stress the advantages of small 
size in terms of greater amenability to economic management and a greater sense of identity and community solidarity among the people of a small nation-state. Finally, they make the valid point that the quality of human resources of a country can more than compensate for a lack of natural resources.

Those who have doubts about the economic viability of very small countries tend to stress the overwhelming significance of economies of large scale in terms of aciministration, national markets, and the scope for the application of efficient capitalintensive technologies. They also point out that in small countries it is difficult to have the wide range of both human and natural resources required for an indigenously motivated pattern of economic development.

One obvious qualification to the simple notion of size is, however, the volume of natural resources, the most outstanding case in point being Kuwait and the United Arab Emirates, which are all richly endowed with petroleum resources in spite of their very small land area and population.

Be this as it may, in terms of the individual countries of both the Caribbean Archipelago and Caribbean community (particularly in the very small islands), natural resources on an individual country basis tend to be either very limited or highly skewed in favor of a certain agricultural or mineral commodity or commodities. Moreover (and again, particularly in the smaller islands), trained human resources are subject to continuous depletion as a result of the brain drain to North America, and, what is more, with populations that are so small in absolute numbers it is extremely difficult to have a sufficiently wide range of the skills required for internally motivated economic and social development.

RATIONALE AND PROBLEMS OF CARIBBEAN

ARCHIPELAGO INTEGRATION

We therefore immediately come upon one of the most central issues in Caribbean economic development - the need for meaningful economic integration. Thus, the prospects for au- 
tonomous development of the Caribbean Archipelago and the more geographically limited Caribbean community would obviously be enhanced by schemes of integration and economic cooperation bringing a wider market and a wider range of human and natural resources (including low density of population in countries such as Belize, Guyana, Suriname, Cayenne, and Cuba).

One important corollary of this point of view is that the prospects for economic and financial viability in the newly independert and about-to-be independent Caribbean countries that are small in terms of population would seem in large measure to depend in most cases on the saccessful implementation of realistic schemes of economic and even political integration and cooperation. This proposition force for those very small English-speaking and Durch-speaking Caribbean countries either newly independent, such as Grenada, or on the verge of independence-the British Associated States of Antigua, Dominica, St. Kitis-Pevis-Anguilla, St. Lucia and $S t$. Vincent, and the Holiand-affiliated Federation of the Netherlands Antilles. Indeed, some, including myself, would go further and argue that the entire English-speaking group of the Leeward and Windward Islands shotld have proceeded to independence as a single group, not only for reasons of size of market and human and natural resource endowment, but also because of the need to achieve more economic and effective administrative services and the need, because of their weakness in all spheres, to present a single front in all external relations and contact with the outside world. A smaller number of persons, again including myself, would go even furthe: and urge the view that the only way in which the small Englishspeaking countries of the eastern Caribbean (not only the Leeward and Windward Islands but also Barbados, Trinidad and Tobago, and Guyana) can achieve meaningful economic and political independence and cultural identity in the face of the powerful external economic, diplomatic, geopolitical, and political forces (emanating from more powerful large and medium-sized states as well as the transnational corpora- 
tions) is by establishing a political unior among themselves. I must, however, admit that in the present climate of West Indian thinking, both these viewpoints would today be regarded as Utopian by all the countries concerned. So the smaller Leeward and Windward Eslands are clearly now proceeding to individual independence, and only time will tell whether their individual indeperdence will ever be a reality from a substantive rather than a formal point of view.

More generally, the immediate or near-îerm scope for Caribbean integration would seem to be reduced by many powerful factors (both historical and contemporary) making for Caribbean fragmentation and disintegration.

Because of the present peculiar constitutional and economic ties which Puerto Rico, U.S. Virgin Hslands. Martinique, Guadeloupe, and Cayenne have with their metropolitan counsries, one cannot at present discuss meanirgfully the inclusion of these territories in any scheme of Caribbean economic integration. For technical economic reasons having to do with the exissence of a centrally planned economy in Cuba, the inclusion of this country in a comprehensive scheme of Caribbean economic iniegration must also be ruled out. On the other hand, there are clearly no such compeiling economic (as distinct from diplomatic and political) reasons why Haiti, Dominican Republic, Suriname, and (in time) an independent Netherlands Antilles should be ruled out from participating in such a scheme. Comprehensive economic integration is one thing. Loose arrangements for economic cooperation and functional collaboration are another. Therefore, there is great immediate scope for a greater degree of economic cooperation and functional collaboration among all the countries and territories of the Caribbean area.

\section{NATIONAL DEYELOPMENT PROBLEMS AND STRATEGIES}

Let us now summarily list the main economic problems facing most of the countries of the Caribbean Archipelago in general, and the Caribbean community in particular, and 
mention brieny the strategies which could be and are in some cases being applied in overcoming these constraints to development.

From the previous discussion in which we dealt with historical legacy and small size, it should not be surprising that the following figure prominently among the development problems of the area:

(a) a very large food import bill amounting for the English-speaking Caribbean countries alone to nearly US $\$ 0.5$ billion or about US $\$ 80$ per head of population-perhaps one of the highes per capita food import bills in the Third World;

(b) a heavily undiversified and specialized structure of production, with dependence on a single crop or a limited number of export products such as sugar, bananas, coffee, citrus, oil and natural gas, bauxite and alumina, and tourism;

(c) corresponding dependence on a very wide range of imports, not only of capital goods but also intermediate goods as well as food and other consumer goods (Cuba and to some extent Guyana are exceptions);

(d) the fact that export agriculture is high-cost and on the decline, partly because of low productivity and partly because of the relatively high wage-rates spilling over from high productivity and better paid sectors (minerals and tourism); sugar, bananas, and citrus are the most seriously affected export crops in the countries belonging to the Caribbean community;

(e) an absence of economic linkages between different sectors of the national economy-e.g., agriculture and industry, agriculkure and Tourism, mining and manufacturing, and so on; manufacturing and tourism, in particular, rely to an excessive degree on inputs imported from outside the area;

(f) the inability so far of the manufacturing sector to achieve significant levels of extraregional exports;

(g) in spite of relatively high levels of per capita income, economies with a strong lack of resilience in the face of adverse economic developments of external origin;

(h) low levels of national savings (in the household, public, and corporate sectors) and corresponding excessively high levels and inappropriate patterns of consumption;

(i) above all, alarmingly high levels of unemployment (ranging from $14 \%$ to $30 \%$ of the labor force) and equally high levels of low-earning underemployment. 
The development strategies that could be implemented (and which are beginning to be implemented by many countries in the area) can easily be seen:

(a) efforts to increase levels of food production for the domestic and regional markets;

(b) efforis to diversify both the internal composition of economic activities and the composition of exports and imports (there is also need to diversify both the country destination of exports and the country source of imports to the extent that doing these things would be economic in the long run);

(c) efforts to promote more linkages as between various sectors and activities of the individual national economies and as between the various sectors and activities of different countries in the region;

(d) efforts to foster trade specialization and cooperation in production at the regional or area levels;

(e) efforts to make more competitive traditional agriculiural expori crops;

(f) efforts to increase sales of manufactured goods extraregionally;

(g) efforts at an "incomes and prices" policy; and

(h) efforts to adapt imported technology as well as to encourage the development and use of technologies more appropriate to the countries of the region.

We must note here that many of the apparently purely economic constraints to Caribbean economic development arise from factors usually relevant to political economy rather than to economics proper. The aversion to both peasant and wage-labor agriculture among many sections of the population is a sociological parameter rooted in the historical legacy of slavery and in the low value and status assigned to agriculture as an occupation. High levels and inappropriate patterns of consumption arise again from the impact of the consumption patterns of the affluent North American and West European societies, imported through the advertising in and the images conveyed by the electronic mass media (particularly television), the presence of many tourists in the countries, and the proximity of North America. The high levels of unemployment can be 
partly explained by the widespread imitative use of inappropriate capital-intensive technologies imporied without modification with a view to betcer suiting local factor endowmenis. They can also be explzined by the deficiencies of a colonial-imherited elitist and often inappropriate system of education, deficien in opportunities and motivations for techracal and vocational training and failing miserably in integrating the "world of school" with the "world of work." Finally, "Western" eypes of trade unionism and generally free collective bargaining processes also facilitate the transmission of high wages from the mineral or tourism sectors into the public and agricultural sectors, making for low or negative public sector surpluses and high costs of agricultural production. But under the political systems existing in most if not all the countries of the area, the application of incomes and prices policies is notoriousiy difficult.

The existence of these "political economy consiraints" on autonomous patterns of development implies that fundamentally the development problems of the area can be tackled effectively only through the political process which would have to undertake the onerous tasks of radically restructuring educational and training systems and initiating changes in values and attitudes in relation to lifestyles, work habits, levels and patterns of consumption, and propensities to technological adaptation and innovation. Let it be noted here that the present political institutions and mechanisms devised to preserve and promote traditional civil and political rights and liberties inherited from the metropolitan powers could, under many circumstances, prove inconsistent (at least in some degree) with the kinds of political processes required to push through the necessary far-reaching changes in values and attitudes.

In the light of the prevailing frailness of economic structures, all the Cariobean countries (with the sole exception of Trinidad and Tobago, a minor exporter and producer of oil by world standards) have been adversely affected by the international economic crisis which had its onset in 1973-1974 resulting in considerably higher prices for oil as well as for 
imports of manufactured goods and food from the industrialized courtries. The subsequent recession in the industrialized coumtries also added to the impact of these adverse developments on the Caribbean countries which were faced with worsening ierms of trade, a slowing down of cemand for their exports in the indusirialized countries, inported infiation, and consequently very severe balamce-of-payments and fiscal difficulties:

The Caribbears And

The New Interrational Economic Order

ROLE OF CARIBBEAN IN DIALOGUE ON NEW ORDER

Many of the independent English-speaking Caribbean countries-panticularly Guyana and Jamaica-have been in the forefrom of the demand for a New Intermational Economic Order. These demands have been made both within the UN system and outside, as in the case of the disappointing NorthSouth dialogue of 1975-1977 in Paris. It would be pointless to list in this essay all of the demands made by the Third World countries in conaction with the proposed New International Economic Order. 1 prefer to list certain broad areas which appear to be of great significance for the Caribbean countries. These are:

(a) stable and remunerative prices for commodity exports of the developing countries;

(b) better access for semimasufactures and manufactures in the markets of the developed countries;

(c) a greater volume of official developmen assistance, as far as possible on concessional terms, and appropriate action on the debt problems of the individual developing countries;

(d) the need to take into account and act on the special needs of developing island economies;

(e) economic cooperation among developing countries; and 
(f) a fairer deal from the transnational corporations in respect of both direct investment and the transfer of technology.

In addition, quite apart from a restructuring of the international economic system, greater internal effort in the fields of food production and the mobilization of domestic financial rescurces have been siressed by some, as has been the need for the pursuit of "basis needs" development strategies--that is to say, strategies that aim at structural iransformation of the economy while also meeting the needs of the poor majority of the population for a more human and less degraded and deprived existence.

To begin with, one has to probe deeply and face up to the question of whether for countries such as the Caribbean preferential treatment in protected developed couniry markets, such as the socialist bloc or European economic community, are not preferable to "universal" schemes such as the UNCTAD proposal. So far as the Caribbean is concerned, this issue primarily centers around the prices and volumes of exports of sugar and bananas, as well as access for semimanufactured and manufactured exports into the markets of the developed countries. But it is not a question of either/or. For to the extent that the Caribbean countries export on the world market outside of these preferential zones, they need both "particularistic" and "universalistic" means of export support.

Indeed, the real significance of the Lomé Convention is that some of the concepts underlying the New International Economic Order have been incorporated into the agreementfor example, mechanisms to avoid or reduce possible political influence on the part of the EEC on the associated developing countries; the removal of the provision in the previous Yaounde Conventions for the granting of "reverse preferences" by the associated developing countries; the recognition of a special category of "least developed" countries; and the encouragement 
of economic cooperation among the associated developing countries; and the incorporation of a Commodity Export Stabilization Scheme (STABEX).

We also should not forget that the extent of trade and possibly aid advantages conferred on the developing countries party to the Lomé Convention is likely to diminish over time, so that ultimately the Caribbean countries will get the same treatment that Europe gives to other developing countries. Accordingly, one can objectively justify the temporary trade advantages available to some of the Caribbean countries under the present and subsequent five-year conventions as a means of enabling them to retain certain preferential treatment which they formerly had in the markets of the metropolitan countries for certain commodities which they produced either at high cost (such as sugar and bananas) or competitively (such as rum). Ir terms of the need for at least temporary props for certain important export products, the Caribbean countries concerned constitute a special case among Third. World countries.

\section{COMMODITIES}

The Caribbean certainly has an interest in the integrated program for commodities elaborated by the UNCTAD Secretariat and discussed in both that forum and in the North-South dialogue in Paris. Of the 18 commodities selected for the common fund approach, sugar, bananas, bauxite, cocoa, and coffee are of interest to the Caribbean.

It has been often urged by reactionary writers that many individual developing countries stand to lose to the extent that they would be net importers of many of the 18 commodities. The Caribbean would certainly be among such developing countries. But this point has, from the outset, been recognized in the UNCTAD secretariat's initial proposal on commodities, where it was recommended that the individual developing countries who lose by having to pay higher prices for one or more imported commodities should receive special compensation in various ways both from the proposed common fund 
and from other sources of external finance. In this connection, one should also take into account the proposal initiated by the Commonwealth group of experts on the Nev International Economic Order that receipts from tourism (an economic activity of great impontance to many of the Caribbean countries) should be taken into account in the operation of the $M M F$ scheme of compensatory financing for export shortalls in developing countries.

\section{MANUFACTURES}

The Caribean, as observed earier, needs to achieve considerable increases in its level of exports of semimanufactures and mamufactures to extraregional markets, and on the face of it would appear to stand to gain considerably from the provision of better access for such products to the markets of the industrialized countries. Many of the coundries of the area already have duty-free access for a wide range of manufactures and semimanufactures into the European economic community under the Lomé Comvention. As developing countries, they also have favorable treatment under the General System of Preferences (GSP) in the markets of developed countries, such as Canada and the United States of America. On the other hand, because of relatively high wage-rates in the face of considerable unemployment, as well as low volume of exports by individual exporting frims, there is reason to believe that high, costs of production and small volumes may not make them as competitive as other developing countries-particularly leading Third World exporters such as South Korea, Taiwan, Singapore, Mexico, Colombia, and Brazil. On these grounds, one can argue that they may not be able to a a ke automatic advantage of the arrangements for duty-free or low-cinty access of both the Lomé Convention and the GSP. But this should not be allowed to obscure the long-term interest which virtually all the countries of the area have, along with other developing countries, in preferential access to the markets of the developed countries. After all, no reasonable government or indi- 
vidual in the Caribbean countries concerned would expect these countries to benefit fully from every single new arrangement made in connection with the New International Economic Order. Third World solidarity is essential; for just as any single Third World country may mot benefic from any one area as much as others, so are there other areas from which a single country may benefie more than others.

\section{OFFICIAL DEVELOPMENT ASSISTANCE}

The Caribbean countries, whatever their size, volume, and range of natural resources or ideological orientation, are heavily dependent on official development assistance and, as small countries, receive as a group one of the highest per capita levels of aid among Third World countries. This applies to Cuba just as much as to Montserrat. This high dependence in the case of any single country is the product of one or more of the following:

- diseconomies of very small scale in administration, public services, public utilities, and infrastructure;

-high rates of consumption and low rates of national saving in relation to Gross National Product;

-in one or two countries, very rapid rates of economic and social transformation desired by the leaders; and

-very tight foreign exchange constraints in the development process.

On the other hand, the larger and relatively more developed countries have been considered "middle-income" countries mot deserving of official economic aid on concessional terms. The call in the New International Economic Order for greater volumes of official development assistance for deveioping countries on concessional terms is therefore clearly to the advantage of all the Caribbean countries.

Some of those Caribbean countries where foreign exchange constraints are very tight are now facing a serious problem 
of external debt service, because of the relatively short maturities which characterize their recent borrowing from private sources and governmental export credit agencies, because of worsened terms of trade, balance-of-payments, and fiscal deterioration for other reasons, and because in the case of the larger and relatively more developed countries, as a result of their relatively high per capita income, they have not received sufficient levels of official development assistance on sufficiently concessional terms. Clearly, all the Commonwealth Caribbean countries could gain to the extent that the external debi problem is realistically tackled by the international community.

\section{DEVELOPING ISLAND ECONOMIES}

Nearly all of the Caribbean countries can be characterized as small or disadvantaged developing island economies. The disadvantages in international economic relations faced by these countries have been well analyzed by the UNCTAD Secretariat. These disadvantages are small domestic markets; separation by sea which makes for high transport costs in both international and intraregional trade, even in an integrated market; lack of diversified economic structures; diseconomies of small scale in public services, public utilities, and infrastructure; absence in most cases of natural resources; and extensive economic dependence on the outside world. Any appropriate set of measures which is undertaken by the internarional community in favor of developing island countries would obviously benefit the Caribbean countries: official lending on highly concessional terms; special assistance of this nature for interisland transport and communications facilities; the use of external financial and technical assistance to promote economic integration and cooperation among groups of neighboring islands; and technical assistance to help such countries to bargain effectively with the transnational corporations so as to improve their terms of access to foreign shipping services, foreign direct investment, and to technology. 
One very important aspect of small size and external economic dependence in the Caribbean countries is the issue of economic cooperation among developing countries.

\section{ECONOMIC COOPERATION AMONG DEVELOPING COUNTRIES}

So far the economic integration experiment has been limited to the English-speaking Caribbean countries and has taken the form of the Caribbean community, of which the most important part is the Caribbean common market. The share of intra-common market trade in total trade grew from $8 \%$ in 1967 (the year before the freeing of trade under CARIFTA in 1968 ) to $11 \%$ in 1973 , and then dropped to $7 \%$ in 1976 . The fact is that the common market is now facing serious difficulties as a result of import restrictions imposed by Guyana and Jamaica against "inessential" products because of their very serious foreign exchange difficulties. Now, as every economist knows, the benefits of economic integration among developing countries are not confined to the benefits arising from trade liberalization. The reason is that in the long run, greater benefits can result from cooperation in production involving the establishment of complementary structures of production and from the establishment of certain common services in areas such as transportation and communications, other infrastructure, research, education, and administration. Member states of the Caribbean common market are now beginning to implement some of the provisions of the treaty, other than those calling for intraregional trade liberalization and the establishment of a common external tariff protective system. A start has been made on the implementation of the regional food plan (including the establishment of the Caribbean Food Corporation to implement the plan), and the first steps are being taken to implement the system of regional industrial programming laid down in the treaty, with priority attention being given to the pulp and paper sector, based on the forestry resources of the region. 
Nevertheless, we cannot too lightiy dismiss the import restrictions on "inessential" light manufactures; for while it is true that (with the exception of petroleum, ferilizer, and rice) most intraregional trade so far consists of products of the light manufacturing sector not based to any significant exrent on local and regional inpurs and therefore containing the minimal local and regional value added required to meet the rules of origin, such industries tend to be relatively labor-intensive, with the result thas restrictions on intraregional trade can produce serious unemployment in those CARICOM countries whose exports are so restricted. This factor of severe restrictions on intraregional trade has led to a certain amount of demoralization but not despair among certain groups in the member states of CARICOM and particularly among those who advocate regional solutions to the development problems of the region.

The solution to these problems of deep structural disequilibrium in the balance-of-payments is for the two or three couniries seriously affected to make the necessary structural adjustments to the large external deficits produced by the international economic crisis and subsequent world recession, and for them to receive balance-of-payments support to help them to adjust quickly and successfully. Fundamentally, full adjustment to this situation can be achieved only by increases of production (of both import substitutes and exports). Trinidad and Tobago, the only oil-producing Caribbean country, thas given a significant amount of balance-of-payments support to its less fortunate sister states by making available US\$150 million since the onset of the world economic crisis in 19731974. It is hoped that Trinidad and Tobago will continue giving such support and that the World Bank, $1 \mathrm{MF}$, and interested donor countries will make available adequate amounts of shortterm, medium-term, and long-term balance-of-payments support to CARICOM countries such as Barbados, Guyana and Jamaica, and development finance on concessional terms to the less developed countries that, because they have no centra! bank and limited monetary independence, experience their 
balance-of-payments problems in the form of large fiscal deficits and shrinkage of both public and private liquidity. To the extent that this is done, and intraregional trade increases to precrisis levels, it should be possible for the regional movement to move increasingly toward more effective cooperation in production and the building up, over time, of more complementary structures of production. At the same time, any efforts among some or all of the smaller countries to establish common services among themselves should be morally and financially supported both within and outside the region. In this way, econornic integration will undoubtedly create, in the long rum, a considerable level of benefits to the Caribbean countries.

Indeed, one essemtial pretequisite for a just and durable scheme of Caribbean economic integration is the provision of the masimum feasible range of opportunities for rapid development in the relatively less developed countries. Just as the developing countries throughous the world are seeking from the developed countries the creation of a new and more just inteprnational order which would make possible their soundly based development, so must justice and equity prevail in economic integration and cooperation schemes among the developing couniries themselves. Fortumately, this need has always been clearly recognized and acted upon within the framework of Caribbean economic integration; for the relatively more-developed countries of the community have always seen that, if it were otherwise, their case for more just and equitable economic treatment by the world's developed countries would have no moral basis.

But there are many, both within the region and outside, who question the effectiveness of the concept of economic integration among such small countries as aid to development and pin their hopes on much wider economic cooperation among larger numbers of Third World countries. To do this, I submit, is to throw out the baby with the bath water. Economic integration among a group of neighboring Third World countries, however small, and economic cooperation 
among a much bigger number of Third World countries are not in confict with, but are complementary to, each other. Indeed, perhaps the best way of setting about economic cooperation among a large number of developing countries is to organize such cooperation on the basis of a gradual development of economic links between subregional integration schemes or between such schemes and individual large developing countries. For if we are to be completely objective, we must face up to the real possibility of relations of dominance and dependence being established, as between Third World countries; for these countries, while they quite definitely have a fundamental unity of interest with each other, vary considerably in size and economic strength. The Caribbean community has a total population of only 5 million persons and consists for the most part of either very small or very weak countries. The community, while seeking to extend the area of economic cooperation with other Third World countries (both in Latin America and outside), should give primary emphasis at this stage to welding itself into a cohesive unit characterized by the closest possible coordination of external economic actions, policies, and relationships. This was, it should be noted, the rationale behind the formation of the Andean group, under which the smaller and medium-sized countries of LAFTA formed a subgroup of their own as a means of cooperating more easily and equitably with Mexico, Brazil, and Argentina, the three giants of $\mathbb{L} \mathbb{A} T A$. Similarly, this type of subregional cohesion provides the only sensible basis on which the Caribbean community countries should enter into very desirable closer economic relationships with the other countries and territories of the Caribbean Archipelago as well as with the large and relatively more developed and powerful Mainland countries of Mexico, Colombia, and Venezuela. The Caribbean community as a group must also maintain its position of negotiating as a group in its developing relations with' other Third World countries both within and outside the African, Caribbean, and Pacific group which have entered into the Lomé Convention with the EEC. 
To say this is not to deny the need for CARICOM to "widen" itself in the medium term to include other Caribbean Archipelago countries such as the Dominican Republic, Haiti, and Suriname and to develop cooperative relationships with countries such as Cuba, the Netherlands Antilles, and even conceivably the French Antillean departments. This process can be initiated by the Caribbean community negotiating either trade or economic complementarity agreements and even associate membership with other Caribbean Archipelago countries. An important step was recently taken toward greater economic cooperation among most of the countries of the Caribbean Archipelago through the establishment in 1975 of the Caribbean Development and Cooperation Committee (CDCC) of the $\mathbb{U N}$ Economic Commission of Latin America (ECLA). "The CDCC of $E C L A$ has the following memberships: Bahamas, Barbados, Cuba, Dominican Republic, Grenada, Guyana, Haiti, Jamaica, Suriname, and Trinidad and Tobago, with the British Associated States, Belize, and the Netherlands Antilles being associate members.

Another possible route to greater economic cooperation among the Caribbean Archipelago countries could emerge to the extent that the proposal for the creation of a Caribbean Group for Economic Cooperation in development comes about. The intention here is that some of the industrialized countries with special links with the Caribbean and some of the mainland countries whose shores are washed by the Caribbean sea join with the CARICOM state of Trinidad and Tobago in cooperating with the majority of the Caribbean Archipelago countries by providing them with additional official development assistance within a multi-lateral framework, whilst encouraging and promoting present integration and new cooperation efforts among the potential beneficiaries of such aid. Such additional economic aiơ is intended to be for a limited period of time to help the recipient countries, which as a result of external international economic factors are now faced with considerable economic and financial difficulties. 
Indeed, the well-recognised |need for the Caribbean countries to have closer economic relationships with the Latin American countries, while preserving their Caribbean economic and cultural identity and increasing the degree of their external economic and diplomatic solidarity, can best be accommodated within a framework under which:

(a) multilateral financial assistance is made available to some or all of the Caribbean Archipelago conntries by the bigger Caribbean basin and other $\mathbb{L}$ atin American countries, through subregional financial institutions controlled by the Caribbean countries, such as the Caribbean Development Bank;

(b) the coumeries of the Caribbean community as a community and nos on an individual basis showld enter into trade and economic complementariôy agreements with other countries of the Archipelago, with the larger sneighboring Caribbean basin and with other Latim American countries. (This is so both because it would strengthen the bargaining power of the individual Caribbean community countries and because it would prevent the preemption by third countries of opportunities for intra-CARICOM trade and economic complementarity and so strengthen the Caribbean community.) One such agreement between Mexico and the Caribbean community has recently been entered into.

FOREIGN INVESTMENT, TECHNOLOGY TRANSFER. AND THE TRANSNATIONAL CORPORATION

Because of the long centuries-old history of economically dependent association of nearly all the countries of the Caribbean Archipelago with developed metropolitan countries, resulting in still too many cases of domination of many key sectors of their economies by the giant transnational corporations, most of the Caribbean countries have an interest in the demands in the New International Economic Order 'for an elimination of the unhealthy economic and political effects of the transnational corporations on the sound and balanced development and sovereign integrity of Third World countries 
and for an improvement in the terms under which the technology developed by these corporations is "transferred" (or, more precisely, sold) to developing countries. Moreover, the call for the development and use of more appropriate technology in Third World countries suffering from heavy structural unexmployment is highly relevant to all the countries of the Caribbean.

Many of the English-speaking Caribbean countriesparticularly Guyana and, to a lesser extent, Jamaica and Trinidad and Tobago-have over the last few years been seeking to reduce dependence on the transnational corporation. Although the need for foreign exchange will continue to be very acute and may well slow down the pace of bringing key sectors of the economies under national control, it would be extremely naive to believe that those Caribbean countries with radical or nationalist economic policies will make a complete about-face and open up their economies indiscriminately to direct foreign investments. What is more likely is the adoption by these countries of more selective and flexible and less dogmatic policies on direct foreign investment and the transnational corporations. Both the improvement of the terms under which technology is "transferred" by the transnational corporations and the local and regional development and application of more appropriate technologies would seem to be tendencies that are likely to be strengthened in the future in all the Caribbean countries.

INTERNAL EFFORTS FOR ECONOMIC TRANSFORMATION

The New International Economic Order deals fundamentally with the deep-seated imbalances in international economic relationships between developing and developed countries. But very few serious Third World advocates of the New International Economic Order would ignore the need for serious internal efforts at mobilization of resources and transformation of economic and social structures. These efforts and transformations, it is generally agreed, should be pursued through vigorous programs for developing food production, for 
mobilizing internal financial resources, and more generally for pursuing a "basic needs" development strategy.

Fortunately, in most of the countries of the Caribbean Archipelago, the need for such internal efforts and such transformations aiming at a socially just pattern of economic growth and development is clearly recognized irrespective of size, economic and political orientation, level and ranges of human and natural resources, and stage of development of the various countries. There are now very few governments in the Caribbean area who would dare to support explicitly the pursuit of economic and social elitism in their development strategies.

\section{CONCLUDING OBSERVATION}

To conclude: all the Caribbean countries have a vital interest in the realization of most of the fundamental proposals for a New International Economic Order. They tend to see the achievement of such an order as widening their development options and so contributing, if not to the ending, at least to the diminution of the area's historical legacy of external economic dependence and fragmentation.

\section{REFERENCES CONSULTED}

American Assembly (1971) The United States and the Caribbean. Tad Szulc (ed.).

Englewood Cliffs, NJ: Prentice Hall.

BEST, L. (1970) Black Power and National Reconstruction. Port-of-Spain, Trinidad: Tapia.

- - (1967) The Economy of the British Commonwealth Caribbean: An Overview-West Indies-Caribbean Economic Relations. Mona, Jamaica: University of the West Indies, Institute of Social and Economic Research (ISER).

_._._. (1966) "Size and survival." New World Q. (Barbados Independence issue).

BREWSTER, H. and C. THOMAS (1967) The Dynamics of West Indian Economic Integration, Studies in Regional Economic Integration, Vol. 1. Mona, Jamaica: University of the West Indies, ISER.

Caribbean Community Secretariat (1973) The Caribbean Community, A Guide. Georgetown, Guyana: Caribbean Community Secretariat. 
Commonwealth Experts" Group (1977) "Towards a new international economic order." A final report by the Commonwealth Experts' Group. London: Commonwealth Secretariat.

DEMAS, W. G. (1976a) "Commitment, skill, and organization." May address at Sixth Annual Board of Governors' meeting in St. Kitts. Barbados, West Indies: Caribbean Development Bank (CDB).

-_- (1976b) Essays on Caribbean Integration and Development. Mona, Jamaica: University of West Indies.

-_- (1974) "West Indian nationhood and Caribbean integration." No. I in a collection of papers published in the series, Challenges in the New Caribbean, David 1. Mitchell (ed.). Barbados: CCC Publishing House.

_- (1965) Economics of Development in Small Countries. Montreal: McGill University.

EMMANUEL, P., V. LEWIS, and A. McINTYRE (1975) "The political economy of independence for the Leeward and Windward lsland." Mona, Jamaica: University of the West Indies, ISER. (mimeo)

GIRVAN, N. (1967) The Caribbean Bauxite Industry. Mona, Jamaica: University of the West Indies, ISER.

- - and O. JEFFERSON [eds.] (1971) Readings in the Political Economy of the Caribbean, Mona, Jamaica: New World Group, Ltd.

HAWKINS, 1. (1976) The Changing Face of the Caribbean. Bridgetown, Barbados, West Indies: Cedar Press.

HUBERMAN, L. and P. M. SWEEZY (1970) Socialism in Cuba. New York and London: Monthly Review Press and Modern Reader Paperbacks.

LEWIS, A. (1972) Statement at the Second Annual Meeting of the Board of Governors of the Caribbean Development Bank, given in Jamaica. Barbados: CDB.

LEWIS, G. K. (1974) Notes on the Puerto Rican Revolution: An Essay of American Dominance and Caribbean Resistance. New York: Monthly Review Press.

___ (1972) The Virgin Islands: A Caribbean Lilliput. Evanston, IL: Northwestern Univ. Press.

- (1968) The Growth of the Modern West Indies. London: MacGibbon \& Kee.

LEWIS, V. (1973) "The Caribbean community: a political analysis." Barbados AdvocateNews (June 14).

McINTYRE, A. (1977) Statement at the Seventh Annual Meeting of the Board of Governors of the Caribbean Development Bank, given in Trinidad. Barbados: CDB.

- (1975) Statement at the 16th Session of the Economic Commission for Latin America (ECLA) held in Port-of-Spain, Trinidad. Santiago, Chile: ECLA.

.._- (1965) Decolonisation and Trade Policy in the West Indies: The Caribbean Transition. Rio Piedras, Puerto Rico: University of Puerto Rico, Institute of Caribbean Studies.

- ... and B. WATSON (1970) Foreign Investment in the Commonwealth Caribbean. Mona, Jamaica: University of the West Indies, ISER.

MATTHEWS, H. L. (1970) Castro. London: Penguin.

MUNRO, T. and R. LEWIS [eds.] (1971) Readings in Government and Politics of the West Indies. Mona, Jamaica: University of the West Indies. Department of Government.

RAMPHAL, S. S. (1975) "To care for CARICOM." Speech given in Jamaica, July 5. _... (1971) Dialogue of Unity: A Search for West Indian Identity. Georgetown, Guyana: Ministry of External Affairs. 
RUBIN, R. and R. P. SCHAEDEL [eds.] (1975) The Haitian Potential: Research and Resources of Haiti. New York: Teachers College Press.

SEGAL, A. (1968) The Politics of Caribbean Integration. Rio Piedras, Puerto Rico: University of Puerto Rico, Institute of Caribbean Studies.

VEGA, B. (1978) "The Caribbean-yesterday and today." Opening address of the Annual Conference of Caribbean Studies Association, Santiago, Dominican Republic.

WILLIAMS, E. (1973a) "The foreign policies of the Caribbean states." Commonwealth J. of Int. Affairs 249.

- (1973b) “A new federation for the commonwealth Caribbean?" Pol. Q. 44 (JulySeptember): $242-256$.

_-_ (1970) From Columbus to Castro. London: Deutsch.

(1944) Capitalism and Slavery.' Chapel Hill: Univ. of North Carolina Press.

William G. Demas has been President of the Caribhean Development Bank since 1974. Earlier he was Secretary-General of the Commonwealsh Caribbean Regional Secretariat (1970-1974) and Permanent Secretary in the Ministry of Planning and Development for his native Trinidad and Tobago and Economic Advisor to its Prime Minister. He studied economics at Cambridge University and is the author of Economics of Development in Small Countries with Special Reference to the Caribbean (McGill University Press, 1965) and Essays on Caribbean Integration and Development (University of the West Indies, 1976). As both a student and practitioner of economic development, he has participated in and followed closely discussions over the last two years on proposals for a New International Economic Order. 
APPENDIX I

Selected Economic Data on Caribbean Area

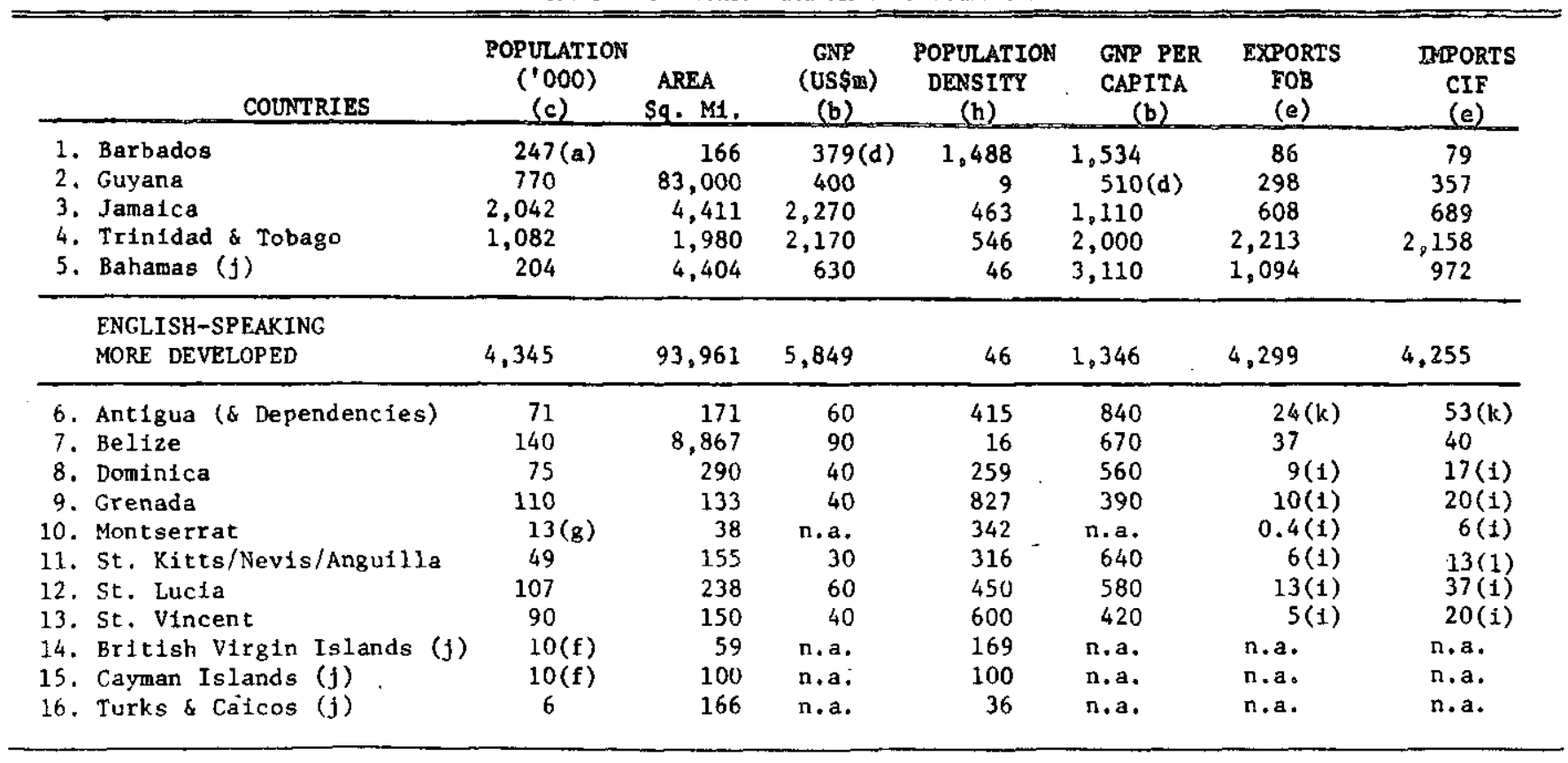


APPENDIX I (Continued)

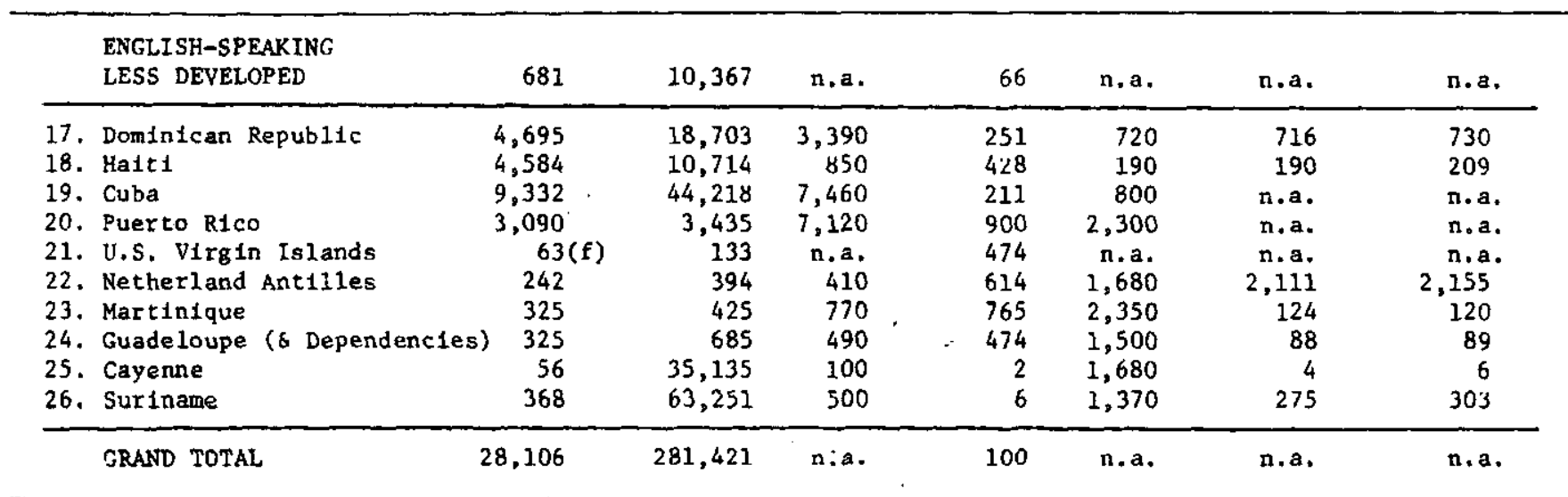

NOTES: n.a. - not available; (a) - mid-1976; (b) - GNP at market prices 1975; (c) - mid-1975; (d) - 1976 data; (e) - U.S. \$m 1976; (f) 1970 Census; (g) - 1972 Census; (h) - population per square mile; (i) - 1975 data; (j) - non-CARICOM country; (k) - 1974 data; (l) - 1973 data.

SOURCES: World Bank Atlas 1977 (World Bank); The Times Atlas of the World (Comprehensive Edition, 1975); International Financial Statistics (IMF. February 1978); Direction of Trade (IMF, 1970-1976); Annual Digest of Statistics 1975 (ECCM Secretariat); Digest of Trade Sta. tistics of CARICOM Member Stotes (CARICOM Secretariat, September 1976). 
APPENDD II

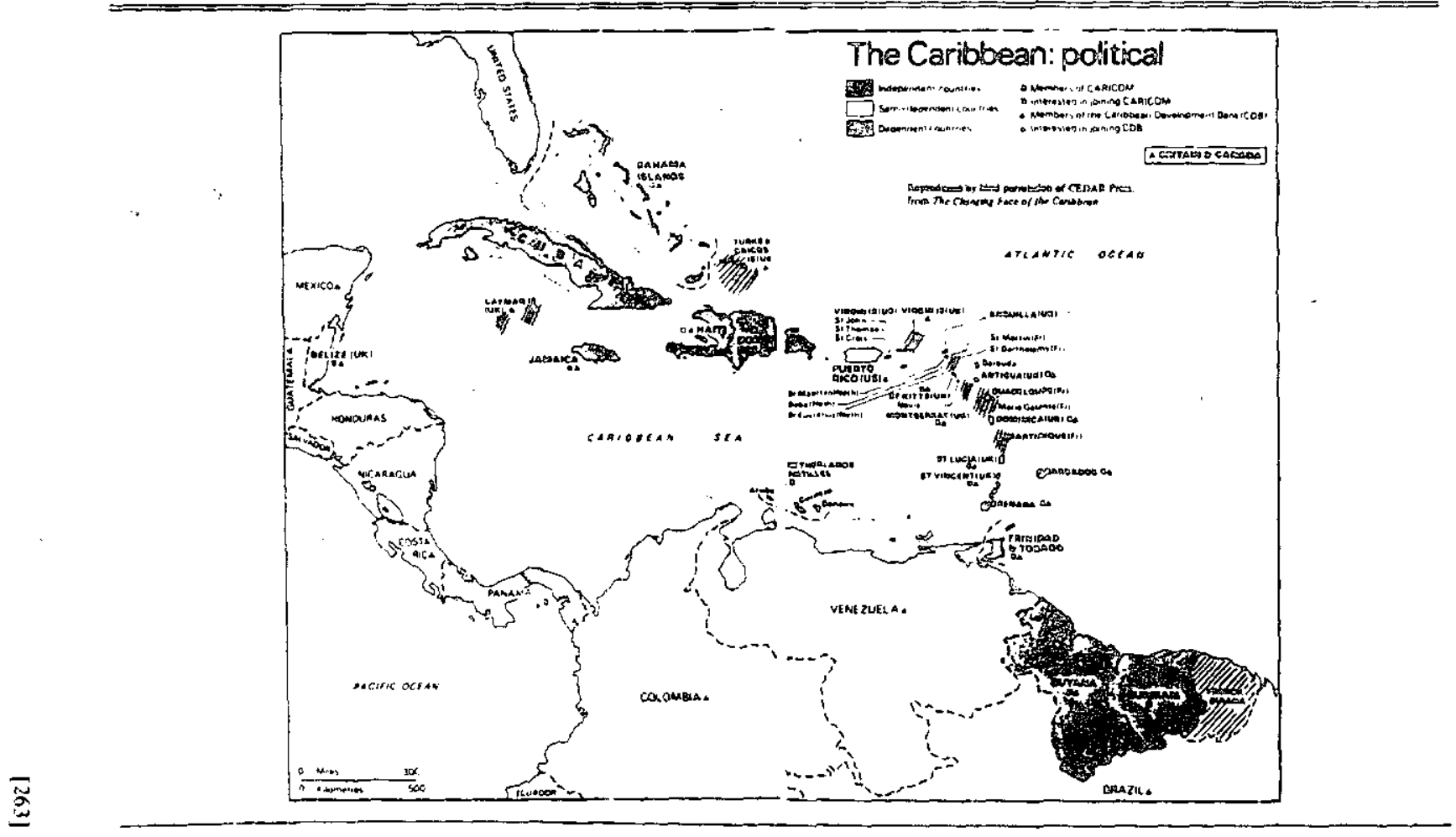


、 